\title{
Forsvarlighetskravet i barneverntjenester
}

\section{Sammendrag:}

Barn og familier kan motta kommunale velferdstjenester i form av helse- og omsorgstjenester og/eller barneverntjenester. Tjenestene kan være like i formål, innhold og saksbehandlingsregler, og begge instanser skal utøve sitt arbeid forsvarlig. Barn og familier må likevel forholde seg til instanser og personale med forsvarlighetskrav som er ulikt beskrevet i lovgivningen. Helselovgivningens mer utfyllende beskrivelser kan gi ulike bidrag til $\varnothing$ kt forsvarlighet i barneverntjenester, herunder ved at instansens og personalets forsvarlighetskrav tilpasses deres målgruppe og mandat og ved lovfesting av kompetansekrav i barneverntjenester.

Nøkkelord: Barneverntjenester, helse- og omsorgstjenester, forsvarlighet i barneverntjenester, forsvarlighetskrav, kompetansekrav

\section{Abstract:}

Children and their families can receive assistance from local authorities such as health- and care services and/or child welfare services. The assistances can be similar in aims, contents and case management regulations, and both instances must exercise prudence in their work. However, children and families must relate to instances and staff who are subject to very different legal requirements prudence. The fuller descriptions of health legislation may provide different contributions to increased child welfare services, including the compliance of the agency and staff with the requirements of their respective target groups and mandates, and by the legalization of competence requirements in child welfare services.

Key words: Child welfare services, health and care services, prudence in child welfare services, competence requirements 


\section{Forsvarlighetskravet i barneverntjenester}

\section{Innledning (1)}

\section{Tema, bakgrunn og problemstilling (1.1)}

Barn er primært foreldrenes ansvar, og foreldre kan få støtte i sine omsorgsoppgaver av flere instanser, herunder barnehage, skole, pedagogisk/psykologiske tjenester, Nav og kommunens helse- og omsorgstjeneste. Barn og foreldre kan oppleve slike hjelpetjenester som mindre stigmatiserende enn barneverntiltak og derfor lettere å ta imot eller søke om, noe som kan bidra til at barnet får nødvendig hjelp (Kane, 2016). For barn i risiko for overgrep eller omsorgssvikt har kommunens barneverntjeneste ansvar for å sikre «nødvendig hjelp og omsorg til rett tid» (Lov om barneverntjenester 17. juli 1992 nr. 100 (heretter: barnevernloven, bvl.) § 1-1).

Som myndighet utsettes barnevernet tidvis for kritikk, og et forhold som påpekes, er at barnevernets arbeid fremstår som uforsvarligi. Dobbeltrollen som hjelper og kontrollør kan ifølge Haugland (2016) tilsløre barnevernets makt. I den mye omtalte saken om «Glassjenta» ${ }^{\mathrm{ii}}$ konkluderte Fylkesmennene i Hordaland, Rogaland og Troms i sin tilsynsrapport (2016) med at jenta ikke hadde fått forsvarlige barneverntjenester, og knyttet manglene til barnevernets undersøkelse, valg av tiltak, oppfølgning, mangelfulle barnets beste-vurderinger samt samarbeid med andre instanser. Barne- og likestillingsdepartementet (2017) fremhever at mange barn som er under tiltak fra barnevernet, har behov for psykisk helsehjelp, og at dette særlig fordrer et samarbeid og samordnet tjenestetilbud fra barnevernet og helsetjenestene. Som en satsing på å styrke nødvendig samordning i tjenestetilbudet skal det innen 2020 etableres omsorgs- og behandlingsinstitusjoner i alle fem barnevernsregionene i Norge for å sikre at barn får samtidig hjelp fra barnevern og psykisk helsevern, samt et styrket hjelpetilbud (Helsedirektoratet, 2015).

Felles for kommunens helse- og omsorgstjenester samt barneverntjenester er et forsvarlighetskrav, som fremgår i de lover som regulerer tjenestene. Barnevernlovens forsvarlighetskrav gir ikke klare retningslinjer for forsvarlighetskravets innhold og rekkevidde eller for hvordan forsvarlighet kan vurderes eller etterprøves som helselovgivningen. Ut fra problemstillingen: Hvordan kan forsvarlighet i barneverntjenester fremmes gjennom lovgivning og tjenesteutфvelse? er det derfor interessant å unders $\varnothing \mathrm{ke} \mathrm{og} \mathrm{sammenligne} \mathrm{hvordan}$ 
forsvarlighetskravet fremstår i lovgivningen for disse to kommunale tjenesteområder, samt undersøke om de nærmere avklaringer og presiseringer i helselovgivningens forsvarlighetskrav kan gi noen retningslinjer som kan bidra til å fremme forsvarlighet $\mathrm{i}$ barneverntjenester.

\section{Barnekonvensjonen og barneverntjenestens mandat (1.2)}

FNs konvensjon om barnets rettigheter (barnekonvensjonen, BK) art. 19 slår fast barnets menneskerettslige krav på myndighetenes beskyttelse mot overgrep og omsorgssvikt. Konvensjonsbestemmelsen beskriver at myndighetenes beskyttelsestiltak bør omfatte former for «påpeking, rapportering, viderehenvisning, unders $\varnothing$ kelse [..]». Myndigheters inngrep i barnets privat- og familieliv skal være hjemlet i lov, barnet har rett til å bli hørt, og ved alle handlinger og avgjørelser som omhandler barn, skal barnets beste være et grunnleggende hensyn (Grunnloven $\S 113$, BK art. 16, 12 og 3).

Kommunens barneverntjeneste har etter barnevernloven. $§ 2-1,5$. ledd ansvar for «det daglige løpende arbeid», som spesifiseres som å gi råd og veiledning, treffe vedtak i henhold til loven, eventuelt innstille til vedtak, forberede saker for behandling i fylkesnemnda samt iverksette og følge opp tiltak. Barneverntjenestens arbeid skal sikre at barn i risiko får nødvendig hjelp og omsorg til rett tid, og bidra til å fremme barns oppvekstvilkår (bvl. § 1-1). Barnet har rett til tilpasset informasjon og medvirkning, og barnets beste skal ha avgjørende vekt ved valg av tiltak (bvl. §§ 6-3 og 1-4).

\section{Kravet til forsvarlighet i forvaltningen (1.3)}

Eckhoff og Smith (2014, s. 42) beskriver hvordan forvaltningens myndighet omfatter hvilke avgjørelser som kan fattes, hvem som kan treffe de ulike avgjørelser, og hvilken fremgangsmåte forvaltningen må følge for at avgjørelsen skal bli bindende. Kravet om lovhjemmel ved myndighetsutøvelse (Grunnloven $§ 113$ ), medfører også at avgjørelser som griper inn i borgernes privatliv skal bygge på kriterier beskrevet i lovgivningen.

Barnevernarbeid innbefatter handlinger og avgjørelser som i stor grad griper inn i barnets og familiens privat- og familieliv, og Kjønstad, Syse og Kjelland (2017 I, s. 461) fremhever at «Bare avgjørelser fattet med hjemmel i klare lovbestemmelser kan gripe [så] dypt inn i individenes personlige rettssfære». Dess mer partenes selvbestemmelse og privatliv blir begrenset, dess større krav stilles angående hvilke handlinger barnevernet kan gjøre, hvilke kriterier som må være oppfylt, og hvordan de skal gå frem i saken. 
Eckhoff og Smith (2014) fremhever forsvarlighet i saksbehandling som en sentral del av uskrevne krav til god forvaltningsskikk, som supplerer lovgivning. Spesielt fremheves kravene om hensynsfullhet og kontradiksjon og opplysningers holdbarhet samt krav til journalføring (2014, s. 196). Graver (2015) fremhever at forsvarlighetskravet har et «bredere nedslagsfelt» enn saksbehandling og derfor også må omfatte forvaltningsorganets vurderinger og avveininger, og det må være forholdsmessighet mellom sakens grunnlag og avgjørelsens innhold.

Den Europeiske Menneskerettighetskonvensjon 1950 (EMK) artikkel 6 stiller krav til myndighetene ved behandling av borgernes sivile rettigheter og plikter. Det kreves at saksgangen er rettferdig, at avgjørelser treffes innen rimelig tid og at avgjørelsesorganet er uavhengig og upartisk. Personer har krav på underretning og muligheter til å ivareta sine egne interesser (EMK art. 6 (1) og (3) (a og b)). Disse hensynene reguleres i Lov om behandlingsmåten i forvaltningssaker 10. februar 1967 (forvaltningsloven, fvl.). Forvaltningen skal utrede saker grundig, forberede og avgjøre saker uten ugrunnet opphold, tjenestemenn skal ikke være inhabile (fvl. §§ 6,11a og 17), og sakens parter har krav på informasjon og forhåndsvarsling (fvl. §§ $11 \mathrm{og} 16$ ). I barnevernssaker har barnet særskilt krav på informasjon og medvirkning (bvl. § 6-2). Barnevernets mandat omfatter å ivareta barns rettssikkerhet, herunder retten til beskyttelse mot overgrep og omsorgssvikt og retten til å få de tjenester de har krav på. Samtidig medfører barnevernets intervensjoner også stor grad av risiko for både barnets og familiens rettssikkerhet ved at de kan bli utsatt for uforsvarlighet $\mathrm{i}$ tjenesteutøvelsen.

\section{Fremgangsmåte og metodiske valg (2)}

For å kunne belyse problemstillingen vil jeg innledningsvis fremstille forsvarlighetskravet slik det fremgår i barnevernloven, og sammenligne med hvordan kravet fremgår av helselovgivningen. Jeg har studert lovgivningen i sammenheng med øvrige rettskilder, som internasjonale menneskerettskonvensjoner, lovforarbeider og juridisk litteratur. For å komme frem til en rettslig akseptabel forståelse av rettsreglene legges etablerte tolkningsprinsipper til grunn (Eckhoff \& Helgesen, 2001). Det innebærer at hvor lovtekstene ikke er selvforklarende, har jeg studert $\varnothing v$ vige rettskilder for å finne lovgiverens intensjon med bestemmelsene. 
For å kunne finne mulige svar på hvordan innholdet i helselovgivningens forsvarlighetskrav kan bidra til økt forsvarlighet i barneverntjenester, har jeg sammenlignet forsvarlighetskravet i helselovgivningen og barnevernlovgivningen med tanke på tjenesteområder, målgrupper, formål, innhold og rekkevidde. Deretter har jeg drøftet hvordan barneverntjenestens forsvarlighetskrav knyttes til alle faser i en barnevernsak: meldinger, undersøkelser, tiltak og avslutning. Til sist har jeg fremhevet noen områder hvor helselovgivningen gir mer tydelige retningslinjer for profesjonsutøvernes forsvarlighetskrav, og drøftet hvordan disse kan bidra til $\varnothing \mathrm{kt}$ forsvarlighet i barneverntjenester.

\section{Barneverntjenestens forsvarlighetskrav (3)}

Barnevernlovens forsvarlighetskrav fremgår av lovens § 1-4 med ordlyden:

\section{«Tjenester og tiltak etter denne loven skal vare forsvarlige».}

Tjenester og tiltak omfatter alt av barneverntjenestens løpende arbeid, herunder deres rådgivning og veiledning, vedtak om samtykkebaserte hjelpetiltak og innstilling til vedtak om tvungne barneverntiltak, saksforberedelser, samt iverksetting og oppfølging av barneverntiltak, jfr. § 2-1.

Ved å tolke bestemmelsen opp mot andre bestemmelser i barnevernloven ser en at forsvarlighetskravet også retter seg til kommunens ansvar for barneverntjenestens personell og for internkontroll med at tjenester og tiltak oppfyller lovgivningens krav, og videre at det omfatter kommunens ansvar for opplæring av barneverntjenestens personell, og at disse er forpliktet til å delta i nødvendig opplæring (bvl. § 2-1, 7. og 2. ledd). Kommunen skal også besørge de nødvendige bevilgninger til barneverntjenestens lovpålagte oppgaver (bvl. § 9-1, 1. ledd).

Begrepet «forsvarlig»er ikke utdypet i lovbestemmelsen med tanke på innhold og rekkevidde. En fortolkning av begrepet kan umiddelbart gi assosiasjoner til begreper som «tilfredsstillende», «betryggende» og «tilstrekkelig», men disse begrepene er like vage og lite avgrensbare som begrepet «forsvarlig». I lovforarbeider (Prop. 106 L (2012-2013), pkt. 1.1) knyttes forsvarlighetskravet til barnevernlovens formål om å sikre nødvendig hjelp og omsorg til rett tid, hensynet til barnets beste og «allmenne rettsprinsipper». Innføringen av et forsvarlighetskrav i barnevernloven ble blant annet begrunnet $i$ at et slikt lovfestet krav ville 
være et viktig signal til tjenesten og brukere og også danne grunnlag for tilsynsmyndighetenes kontroll av tjenestens forsvarlighet (pkt. 17.2.1).

Angående forsvarlighetskravets innhold og avgrensning uttaler departementet $\mathrm{i}$ proposisjonens pkt. 17.4 at

«det nærmere innhold [vil] utvikles over tid og med utgangspunkt i anerkjent faglig praksis i barnevernet, fagkunnskap fra utdannings og forskningsinstitusjonene, faglige retningslinjer og generelle samfunnsetiske normer i samfunnet».

I samme punkt fremholdes det at det ikke vil være «mulig eller hensiktsmessig å gi en detaljert og uttømmende beskrivelse av hva som vil være innenfor eller utenfor kravet til forsvarlighet» fordi det vil endres ut fra brukeres behov og barnevernets utvikling av fagkunnskap. Departementet bruker her begrepene fagkunnskap, utvikling av fagkunnskap og anerkjent faglig praksis uten å vise til hvilke krav man tenker ligger til slik kunnskap eller praksis, eller hvor store avvikene fra god praksis kan være før tjenesten blir uforsvarlig.

Angående forsvarlighet i barnevernets saksbehandling peker Kjønstad, Syse og Kjelland (2017) på sentrale menneskerettslige krav, herunder personers rett til informasjon, medvirkning og kontradiksjon, innsyn i saken, grundige og upartiske unders $\emptyset$ kelser og at saker avgjøres innen rimelig tid. Barnets egne rettigheter til informasjon og til å bli hørt skal sikres. Disse kravene gjelder i hele saksbehandlingsperioden. I barneverntjenestens saksbehandlingsrundskriv (Barne-, ungdoms- og familiedirektoratet, 2017) uttales det i pkt. 1.1.1.5 at «kjernen i forsvarlighetskravet er vurderinger av hva som kan betegnes som god praksis», dvs. «forankret i anerkjent fagkunnskap og faglige anbefalinger», og videre at

«[k]valitetsmålene innebærer at barn og familier skal få hjelp som virker, at de møter trygge og sikre tjenester og at de blir involvert og har innflytelse. Videre skal barn og familier møte tjenester som er samordnet og preget av kontinuitet, og de skal oppleve at ressurser utnyttes godt og at barnevernet sørger for likeverdige tjenester».

Forsvarlighetskravet er dermed en rettslig standard, som innebærer at kravets innhold må vurderes ut fra både rettslige og faglige forhold som barnevernlovens formålsbestemmelse, kravet om lovhjemmel for inngrep og kravet om særskilt vurdering av barnets beste i den enkelte sak. Innholdet i forsvarlighetskravet kan også suppleres av sosialarbeidernes yrkesetikk (Fellesorganisasjonen, 2015) og barnevernets grunnleggende prinsipper, herunder biologisk prinsipp og det mildeste inngreps prinsipp (Kjønstad, Syse \& Kjelland, 2017). Rent rettslig utgjør forsvarlighetskravet en form for minstestandard, men da barnevernets arbeid 
skal fremme formål om å «sikre» nødvendig hjelp i tide for barn i risiko ut fra hensynet til barnets beste, fremstår det som klart at en generell praksis om å tilfredsstille en minstestandard ikke vil kunne oppfylle forsvarlighetskravet $\mathrm{i}$ individuelle saker. I lovforarbeider til ny barnevernlov (NOU 2016: 16) fremmes forslag om en lovfesting av barnets rett til forsvarlig omsorg og beskyttelse, hvor trygghet, kjærlighet og forståelse betegnes som sentrale elementer (Del 20, lovforslag § 2), Begrepet kjarlighet ble foreslått av Barnevernsproffene, begrunnet $\mathrm{i}$ å «inspirere barnevernsarbeidere til å jobbe med varme $\mathrm{i}$ hjertet og på måter som bygger tillit og trygghet hos barn» (NOU 2016: 16, pkt. 5.2.3.2).

For å forstå innholdet og rekkevidden i forsvarlighetskravet i barnevernloven $\S 1-4$ må en altså se lovens ordlyd i sammenheng med flere ulike rettskilder. Sammenholdt med barnevernloven kapittel 2 og 9 om ansvarsområder, barnevernlovens og forvaltningslovens saksbehandlingsregler, lovforarbeider, rundskriv og faglitteratur kan en slutte at barneverntjenestens forsvarlighetskrav retter seg mot handlinger, beslutninger og vedtak, både med tanke på innhold og fremgangsmåte. Forsvarlighet fordrer dermed tilstrekkelig kvalitet i praksis, dvs. ivaretakelse av brukernes rettssikkerhet både med tanke på barnets rett til beskyttelse og barnets/foreldrenes rett til medvirkning. Dette fordrer igjen adekvat fagkunnskap hos profesjonsutøverne og forsvarlighetsfremmende organisering av instansene.

\section{Kommunale helse- og omsorgstjenesters forsvarlighetskrav (4)}

Hvor barnevernloven kun fastslår at Tjenester og tiltak [..] skal vare forsvarlige, er forsvarlighetskravet i kommunale helse- og omsorgstjenester mer spesifikt utformet $\mathrm{i}$ lovgivningen. Av helse- og omsorgstjenesteloven fremgår det at:

«Helse-eller omsorgstjenester som tilbys eller ytes etter loven her skal vare forsvarlige. Kommunen skal tilrettelegge tjenestene slik at:
a. den enkelte pasient eller bruker gis et helhetlig og koordinert helse- og omsorgstjenestetilbud,
b. den enkelte pasient eller bruker gis et verdig tjenestetilbud,
c. helse- og omsorgstjenesten og personell som utfører tjenestene blir $i$ stand til å overholde sine lovpålagte plikter og
d. tilstrekkelig fagkompetanse sikres i tjenestene». 
Når barn og deres familier mottar kommunale helse- og omsorgstjenester utført av helsepersonell, skal personellet også forholde seg til forsvarlighetskravet i Lov om helsepersonell 2. juli 1999 nr. 64 (heretter: helsepersonelloven, hpl.), lydende:

«Helsepersonell skal utføre sitt arbeid $i$ samsvar med de krav til faglig forsvarlighet og omsorgsfull hjelp som kan forventes ut fra helsepersonellets kvalifikasjoner, arbeidets karakter og situasjonen for øvrig.

Helsepersonell skal innrette seg etter sine faglige kvalifikasjoner, og skal innhente bistand eller henvise pasienter videre der dette er nødvendig og mulig. Dersom pasientens behov tilsier det, skal yrkesutøvelsen skje ved samarbeid og samhandling med annet kvalifisert personell».

Lovforarbeidene til helse- og omsorgstjenesteloven (Prop. 91 L (2010-2011), pkt. 20.2) fremholder at kravet til forsvarlighet i tjenestene innebærer

«en overordnet plikt til systematisk styring av virksomhetene i helse- og omsorgstjenenesten, plikter for utøvende personell om forsvarlig yrkesutøvelse og et kvalitativt og kvantitativt krav til de tjenestene som ytes til den enkelte pasient eller bruker».

Helsepersonellovens forsvarlighetskrav omfatter både helsepersonell og øvrig personell i helse- og omsorgstjenesten som «utfører handlinger» med forebyggende og omsorgsformål (lovens $\S \S 3$ og 4). Ved innføring av forsvarlighetsbestemmelsen i helsepersonelloven fremholdt departementet at «[h]ensynet til forutberegnelighet for helsepersonell taler for konkretisering [av forsvarlighetskravet]» (Ot.prp. nr. 13 (1998-99), pkt. 4.2.5.1).

Forarbeidenes pkt. 4.2.5.3 fremholder at forsvarlighetskravet er «en plikt til å opptre i samsvar med faglige normer og lovbestemte krav for yrkesutøvelsen». I forarbeidenes pkt. 4.2.2 beskrives at helsepersonells forsvarlighetskrav i hovedsak utledes av deres utdanning, praksis og forventede kompetanse, og at de plikter å «både å kjenne til egne faglige begrensninger og til å innrette yrkesutøvelsen etter dette». Forarbeidene viser videre til at yrkesetiske retningslinjer for ulike profesjoner kan være retningsgivende for forsvarlighetskravets innhold. Også godt innarbeidede rutiner kan være uforsvarlige, og brudd på forsvarlighetskravet kan sanksjoneres, herunder gjennom tap av autorisasjon (Ot.prp. nr. 13 (1998-99)). Forarbeidene pkt. 4.2.5.3 fremholder videre at forsvarlighet innebærer som utgangspunkt å ikke «gå inn i situasjoner de ikke er kvalifisert for å håndtere», henvisning til annet kompetent helsepersonell dersom egen kompetanse ikke er adekvat, plikt til å holde seg faglig a jour og til å fremtre «hensynsfullt og ordentlig» overfor pasientene.

Forsvarlighetskravet ligger også på helsetjenestens virksomhetsområder, som har et overordnet ansvar for å organisere tjenestene på en måte som muliggjør at helsepersonellet 
kan oppfylle sitt forsvarlighetskrav (hpl. § 16, 1. ledd). Kjønstad (2007, s. 227) påpeker at «[j]ussen kan ikke gi noe svar på hva som er faglig korrekt eller faglig forsvarlig», men at «[d]et som er korrekt og forsvarlig ut fra helsefagenes egne kunnskaper, innsikter og holdninger» som utgangspunkt vil falle innenfor forsvarlighetskravet i helsepersonelloven. Kjønstad, Syse og Kjelland (2017, s. 203) beskriver helse- og omsorgstjenestens forsvarlighetskrav som «nødvendig hjelp med en forsvarlig standard, basert på en individuell helsefaglig og/eller sosialfaglig vurdering av den enkelte pasient og brukers behov». Ifølge Kjønstad (2007, s. 228) innebærer «omsorgsfull» en etisk og humanistisk dimensjon. Forfatteren viser til Molven (2006), som forklarer dette med «respekt, verdighet, innlevelse, imøtekommenhet» og «vanlig god folkeskikk». Videre skal deres tjenesteutøvelse være tilpasset deres fagkompetanse, og de plikter å involvere annet og bedre kvalifisert personell når det er nødvendig og mulig (hpl. § 4, 2. ledd). I bestemmelsens tredje og fjerde ledd innbefatter forsvarlighetskravet at visse former for tjenesteutøvelse skal påligge særskilt utpekt personale ut fra deres profesjon og kvalifikasjoner. Lovens $\S 16$ pålegger også en organisering av virksomheter som gjør personellet «i stand til å overholde» forsvarlighetskravet.

Sett under ett beskriver helse- og omsorgstjenestelovens og helsepersonellovens ordlyd alene at forsvarlighet omfatter helhetlige, koordinerte og verdige tjenestetilbud, adekvat organisering og fagkompetanse og arbeidsoppgaver tilpasset personellets kvalifikasjoner. I tillegg påligger en plikt til å involvere mer kvalifisert personell. Også for de kommunale helse- og omsorgstjenester er forsvarlighetsbegrepet utfyllende beskrevet i lovforarbeider og faglitteratur. En sammenligning av lovtekstene alene viser likevel at forsvarlighetskravet er atskillig mer tydelig og avgrenset for kommunale helse- og omsorgstjenester enn for kommunale barneverntjenester.

\section{Forsvarlighet i barneverntjenestens avgjørelsesgrunnlag og avgjørelser} (5)

\section{Gjennomgang og vurderinger av meldinger (5.1)}

Når barneverntjenesten mottar bekymringsmeldinger, skal disse gjennomgås snarest og senest innen en uke. Her innebærer forsvarlighetskravet at gjennomgangen sikrer iverksettelse av unders $\varnothing$ kelse når det er «rimelig grunn til å anta at det foreligger forhold som kan gi grunnlag 
for tiltak [..]» (bvl. § 4-2). Det må vurderes hvorvidt meldingens innhold oppfyller lovens vilkår for å starte unders $\varnothing$ kelse, eventuelt om barneverntjenesten skal be melder om å utdype innholdet. I barnevernlovens forarbeider beskrives det at vurderingen må omfatte avveininger av «hensynet til privatlivets fred» og «behovet for å bringe klarhet i forholdet av hensyn til ett eller flere barn» (Ot.prp. nr. 44 (1991-92), s. 107). Barneverntjenesten må også gjøre faglige og etiske vurderinger; hvilke risiko- og behovsområder for barnet identifiseres ut fra de opplysninger som gis? Hvilke implikasjoner vil en intervensjon gjennom en barnevernunders $\varnothing$ kelse ha på barnet og familien som er i krise, og også opplever intervensjonen som en eskalering av krisen? Hvordan kan slik krise påvirke kommunikasjonen mellom barneverntjenesten og foreldrene? Kan utfordringer som skisseres i meldingen, skyldes andre forhold enn foreldrenes omsorgsevne? Kan barnets behov avhjelpes av andre instanser?

Ut fra disse vurderingene skal barneverntjenesten beslutte å enten henlegge saken eller å iverksette undersøkelse dersom vilkårene i barnevernloven $§$ 4-3 er til stede. I en undersøkelse om barnevernets henleggelser av meldinger som omhandler vold og seksuelle overgrep (Kjær \& Mossige, 2013), fremgår det at relativt mange meldinger ble henlagt på grunnlag av «for lite opplysninger», og at enda flere ble henlagt uten noen form for begrunnelse. Manglende begrunnelse for henleggelse av såpass alvorlige meldinger kan ifølge forfatterne innebære at barnevernet unndrar seg sitt faglige ansvar. Backe-Hansen uttrykker bekymring for at barnevernsystemet overbelastes av saker som kunne vært løst av andre instanser, og at barnevernet derfor ikke får tilstrekkelig tid til de alvorligste sakeriii. Kojan, Marthinsen og Christiansen (2016) fremhever at tverretatlig samarbeid mellom barneverntjenesten og instanser som arbeider med barn, kan virke avklarende for hvorvidt ulike bekymringer rundt et barn er av en slik art at de bør meldes. Dette kan bidra til bekymringsverdige forhold blir meldt, og at meldinger blir tilstrekkelig opplyst.

Beslutninger om å henlegge meldinger regnes ikke som et enkeltvedtak etter forvaltningslovens $\S 2$, 1. ledd, og derfor inntrer ikke begrunnelsesplikten etter lovens $\S 24$. Samtidig er nettopp denne beslutningen av stor betydning for barnets rett til beskyttelse og rett til frihet fra ulovmessig innblanding fra myndighetene. En forsvarlig saksbehandling tilsier derfor at henleggelsesbeslutninger begrunnes skriftlig, også for senere kontroll av tilsynsmyndigheter. I saker hvor barneverntjenesten opplever bekymringer rundt barnet, men henlegger dem uten undersøkelse fordi de ikke kan godtgjøre at vilkårene for undersøkelse er til stede, er det særlig viktig at deres begrunnelse for avgjørelsen dokumenteres. I forbindelse 
med endringer i barnevernloven er det derfor foreslått at henleggelser av bekymringsmeldinger skal omfattes av enkeltvedtak med lovbestemt krav til skriftlig begrunnelse (NOU 2016: 16).

Oppsummert innebærer forsvarlighet i meldingsfasen at barneverntjenesten evner å identifisere hvilke forhold som innebærer risiko for barnet, for slik å kunne avklare hvorvidt barnet har behov for barneverntiltak. Dette fordrer at barnevernets personale har tilstrekkelig kompetanse og tid, samt at barneverntjenesten har tydelige rutiner for meldingsgjennomgang.

\section{Fremgangsmåte og vurderinger i unders $\varnothing$ kelser (5.2)}

Barneverntjenestens adgang og plikt til å iverksette en undersøkelsessak inntrer dersom det etter meldingsgjennomgang er «rimelig grunn til å anta at det foreligger forhold» som kan gi grunnlag for et barneverntiltak (bvl. §§ 4-3, 1. ledd). Iverksettelse av en barnevernunders $\varnothing$ kelse omfattes heller ikke av begrunnelsesplikten som er knyttet til enkeltvedtak. Likevel vil barneverntjenestens informasjons- og veiledningsplikt (bvl. §§ 4-4, 2. ledd og 6-4, fvl. § 11) medføre at foreldrene og eventuelt barnet skal få informasjon om grunnene til at de velger å iverksette undersøkelse.

Barneverntjenesten skal «påse at saken er så godt opplyst som mulig før vedtak treffes» (fvl. § 17), samtidig som undersøkelsen ikke skal «gjøres mer omfattende enn formålet tilsier» og gjennomføres så varsomt som mulig (bvl. § 4-3). I lovens forarbeider beskrives dette som å «gå så varsomt fram som sakens alvor tillater» (Ot.prp. nr. 44 (1991-92), s. 107). Hvor omfattende unders $\varnothing$ kelsen skal være, avhenger derfor av alvorsgraden i de opplysninger barneverntjenesten allerede har etter meldingsgjennomgang, men vil måtte justeres ut fra opplysninger som kommer inn under undersøkelsen. Innhenting av opplysninger skal «så langt som mulig» innhentes i samarbeid med parten(e), og både foreldre og barn har krav på informasjon og innsyn i saken (bvl. §§ 6-3 og 6-4, fvl. §§ 18 flg.).

Barneverntjenesten må besørge et godt faktagrunnlag for å kunne gjøre adekvate vurderinger. At det pågår en barnevernunders $\varnothing$ kelse, er et forhold som ikke skal bli «spredt unødig» (bvl. § 4-3, 2. ledd), og det fordrer konkrete begrunnelser for hvilken informasjon som skal innhentes, fra hvilke instanser, og med hvilket formål. Videre skal barneverntjenesten tilrettelegge for samtaler med barnet for å ivareta dets rett til medvirkning (bvl. § 4-1, siste ledd), så personellet må vurdere hvorvidt, og i så fall hvordan, barnet selv skal involveres i 
undersøkelsen. Det må også vurderes hvorvidt det skal gjennomføres hjemmebesøk eller enesamtaler med barnet, og om det skal engasjeres en sakkyndig for å gjennomføre en utredning som ledd i undersøkelsen (bvl. § 4-3, 4. ledd). Ifølge lovforarbeidene er formålet med en sakkyndig utredning å «få et godt barnefaglig grunnlag for de beslutninger som tas» og at det er barneverntjenesten som vurderer og bestemmer hva den sakkyndige skal utrede (Ot.prp. nr. 68 (2007-2008), s. 6 og 10). Dette fordrer at barneverntjenestens ansatte kan identifisere grensene for sin egen kompetanse, og slik kunne avgjøre hvorvidt sakkyndig skal engasjeres.

Barneverntjenesten må også være oppmerksom på om barnet har behov for bistand fra andre instanser (eksempelvis helsevesenet), eller eventuelt er i en akutt situasjon som krever umiddelbar handling i form av midlertidig vedtak etter barnevernloven § 6-4. Samtidig må de identifisere om barnets behov kan avhjelpes av andre organer. Dette forutsetter at barnevernansatte kjenner til hjelpeinstansers ansvarsområder og tjenestetilbud, at de informerer foreldre og barnet om disse muligheter, og også eventuelt hjelper å fremsette søknad til rett instans. Eksempelvis kan nevnes $\varnothing$ konomiske problemer i familien og helseproblemer eller lærevansker hos barnet. Av de 83970 barnevernstiltak som var registrert ved utgangen av 2016, var 31006 registrert under «tiltak for å styrke utviklinga til barnet», herunder barnehage, SFO, økonomisk hjelp, støttekontakt, utdanning og andre tiltak. I tillegg var 9350 tiltak registrert under «samarbeid med andre instanser» ${ }^{\text {iv }}$. Tallene alene kan tyde på at tverretatlig samarbeid vil kunne avklare hvilke bistandsformer som kunne vært hensiktsmessig for barnet, og som for familien kunne oppleves som mindre inngripende enn et barneverntiltak.

I barneverntjenestens saksbehandling vil forsvarlighetskravet være knyttet til de generelle saksbehandlingsregler i forvaltningsloven og barnevernloven. Barneverntjenesten skal informere barn og foreldre om deres rettigheter i en barnevernsak (fvl. § 11) og gi veiledning for å «bidra til å gi det enkelte barn gode levekår og utviklingsmuligheter» (bvl. § 4-4, 1. ledd). Barneverntjenesten må overholde de gitte frister for meldingsgjennomgang og unders $\varnothing$ kelse (bvl. $\S \S 4-2,4-3,1$. ledd og 6-9, 1. ledd). Innhenting av opplysninger fra andre i en undersøkelsessak skal gjøres med samtykke fra foreldrene og eventuelt barnet (bvl. § 6-4, 1. ledd). Videre må barneverntjenesten sørge for at partene får oppfylt sine rettigheter til innsyn i sakens dokumenter (fvl. §§ 18-20). Barnets rett til å bli hørt må tilrettelegges blant annet ved å gi barnet tilpasset informasjon (bvl. §§ 4-1, 2. ledd og 6-3, 1. ledd). 
Barnevernloven og forvaltningsloven pålegger ikke barneverntjenesten en eksplisitt dokumentasjonsplikt, men Lov om arkiv 4 desember $1996 \S 6$ pålegger alle offentlige organer å ha arkiv, og «desse skal være ordna og innretta slik at dokumenta er tryggja som informasjonskjelder for samtid og ettertid». Ifølge Kommunesektorens organisasjon (KS) (2017, s. 8) hører det med til «god forvaltningsskikk og sørge for tilstrekkelig journalføring og arkivering, slik at det kan gjøres rede for hva som er gjort i saken». For tjenester som utøves av kommunens helse- og omsorgstjeneste, har personellet plikt til å føre journal med «relevante og nødvendige opplysninger om pasienten og helsehjelpen» (hpl. §§ 39 og 40). I forarbeidene til ny barnevernlov (NOU 2016: 16) foreslås innføring av journalføringsplikt med opplysninger om barnet og dets omsorgssituasjon, hvordan barneverntjenesten har tilrettelagt for barnets medvirkning, referat fra møter i saken og beskrivelser av barneverntjenestens faglige vurderinger i saken. Forsvarlighet i tjenesten omfatter derfor også å dokumentere arbeidet i barnevernssaker.

Oppsummert vil forsvarlighet i unders $\varnothing$ kelsesfasen omhandle å identifisere bekymringsverdige forhold i barnets situasjon samt vurdere hvordan disse forholdene best kan avhjelpes gjennom tiltak med eller uten barneverntjenestens videre involvering. Også undersøkelsesfasen fordrer personale med tilstrekkelig kompetanse, tid og rutiner. De må også ha adekvate rutiner for kartleggingsverktøy for å kunne vurdere og synliggjøre hvilke områder de vil undersøke og hvilke fremgangsmåter de vil anvende, for å innhente et tilstrekkelig faktagrunnlag for videre faglige og juridiske vurderinger. I dette ligger å ha klare skriftlige retningslinjer for hvordan både foreldrenes og barnets rett til informasjon og medvirkning skal sikres. Undersøkelser må dokumenteres grundig med tanke på hva som begrunnet igangsettelse, hvordan unders $\varnothing$ kelsen er planlagt og gjennomført, hvordan de innkomne opplysninger er blitt vurdert, hvordan foreldre og eventuelt barnet selv har fătt medvirket i saken, samt begrunnelser for undersøkelsens utfall.

\section{Vedtak, evaluering og avslutning av tiltak (5.3)}

Et vedtak om samtykkebasert hjelpetiltak skal være basert på barnets behov og slik være en konklusjon bygd på tilstrekkelige utredninger av barnets og familiens faktiske situasjon og faglige vurderinger av barnets behov. Vedtaket skal være hjemlet i lov, og valgt(e) tiltak skal kunne bidra til positiv endring hos barnet eller i familien. Valget skal ivareta hensynet til barnets beste, herunder barnets rett til å bli hørt (bvl. §§ 4-4, 1. og 2. ledd, og 6-3). Vedtak om samtykkebasert hjelpetiltak etter barnevernlovens barnevernloven § 4-4 er et enkeltvedtak 
som skal skriftliggjøres og begrunnes (fvl. §§ 2, 1. ledd b, 24 og 25). Forsvarlighetskravet innebærer her at barneverntjenesten i sin vedtaksbegrunnelse skal synliggjøre hvordan de har utredet saken før vedtak ble truffet (jfr. fvl. § 17), det vil si hvilket faktagrunnlag, hvilke faglige skjønnsvurderinger og hvilket lovgrunnlag som ligger til grunn for at hjelpetiltak blir iverksatt, og for hvilke(t) tiltak som er valgt.

Et viktig perspektiv angående forsvarlighet ved samtykkebaserte barneverntiltak er at selv om de betinger samtykke fra foreldre og eventuelt barnet selv, så er ikke samtykket nødvendigvis et uttrykk for deres frie vilje, selv om slike hjelpetiltak også omtales som «frivillige». Samtykket kan i noen saker være sterkt påvirket av at barneverntjenesten har rådet foreldrene til det, og at foreldrene har opplevd seg presset til å samtykke for å unngå et mulig tvangstiltak.

Barneverntiltak skal følges opp for å sikre kontinuerlig vurdering av om at tiltak(ene) faktisk bidrar til positiv endring for barnet. Det må vurderes om det er nødvendig med nye tiltak, eller om det er grunnlag for omsorgsovertakelse (bvl. § 4-5). Forsvarlighet i oppfølgning fordrer også at utviklingen hos barnet følges nøye opp, slik at barneverntjenesten kan identifisere hvorvidt barnet har behov for utredning, eventuelt bistand, fra andre hjelpeinstanser (eksempelvis PP-tjenesten eller BUP). Barneverntjenestens oppfølgning og tilhørende vurderinger må dokumenteres for å sikre at hjelpetiltak blir avsluttet, endret eller erstattet med andre tiltak dersom de(t) iverksatte tiltak ikke var adekvat eller tilstrekkelig til å oppnå positiv endring for barnet. Barnets menneskerettslige krav på beskyttelse mot overgrep og omsorgssvikt tilsier at dersom et barn er i en omsorgssviktsituasjon hvor hjelpetiltak ikke avhjelper, skal barneverntjenesten ikke vente unødig med å vurdere å fremme en sak om omsorgsovertakelse. Dermed vil barn og foreldre bli utsatt for en viss grad av kontroll. Et annet forhold er at ved brudd i forsvarlighetskravet i barneverntjenestens utredning og vurderinger, herunder partenes rett til medvirkning, øker risikoen for at det valgte tiltak ikke er egnet til for å føre til en positiv endring for barnet, noe som igjen kan medføre at barneverntjenesten foreslår et tvungent tiltak.

En barnevernsak kan avsluttes etter at barnet har mottatt hjelpetiltak i kortere eller lengre tid, basert på faglige vurderinger av barnets faktiske situasjon. I noen saker kan barneverntjenesten fortsatt være bekymret for barnet, men saken avsluttes fordi barnets foreldre ikke vil samtykke til hjelpetiltak, og barneverntjenesten ikke kan dokumentere at de strengere vilkår for tvangstiltak ikke er til stede. I slike saker bør barneverntjenestens begrunnelse for avslutning av saken særlig dokumenteres, herunder bør det synliggjøres 
hvorvidt barneverntjenesten har veiledet og eventuelt bistått foreldrene og eventuelt barnet til å søke om andre tjenester som kan imøtekomme barnets behov.

\section{Helselovgivningens bidrag til $\varnothing \mathrm{kt}$ forsvarlighet i barneverntjenester (6)}

\section{Et forsvarlighetskrav tilpasset barneverntjenestens målgruppe og særlige mandat (6.1)}

Barn og deres familier kan motta kommunale velferdstjenester i form av eksempelvis avlastning/besøkshjem eller støttekontakt, som enten helse- og omsorgstjeneste eller barneverntiltak. Tjenestene kan ha relativt likt innhold og formål (fremme sosial trygghet og forebygge sosiale problemer, jfr. helse- og omsorgstjenesteloven § 1-1 (2), sikre barn nødvendig hjelp og omsorg, jfr. barnevernloven $\S 1-1)$. Kriteriene for tjenestene er likevel ulike. Barnets og familiens rett til tiltaket som kommunal omsorgstjeneste betinges av at tjenesten er «nødvendig» for barnet og/eller foreldrene (Lov om pasient- og brukerrettigheter 2. juli 1999, § 2-1), mens retten til et hjelpetiltak krever at barnet har et «særlig behov for det» (bvl. § 4-4, 2. ledd), og at tiltaket skal «bidra til positiv endring hos barnet eller i familien». Saksbehandlingsreglene i forvaltningsloven er felles for begge kommunale instanser. For helse- og omsorgstjenesten suppleres disse med særlige saksbehandlingsregler i lov om pasient- og brukerrettigheter og for barneverntjenesten med særlige saksbehandlingsregler i barnevernloven.

Til tross for at formål, innhold og saksbehandling knyttet til tjenesteformene er relativt like, vil barn og deres foreldre måtte forholde seg til instanser og personell med ulike forsvarlighetskrav. Ved kommunale omsorgstjenester omfatter kommunens og personellets forsvarlighetskrav, etter lovens ordlyd, at tjenestene skal være helhetlige, koordinerte og verdige, utført av personell som har tilstrekkelig kompetanse til å utføre de konkrete arbeidsoppgaver, og organisert på en måte som fremmer personellets forsvarlighet i sin tjenesteut $\varnothing$ velse. Dersom barnet får tilsvarende eller lignende bistand etter barnevernloven, innebærer forsvarlighetskravets ordlyd at tjenestene eller tiltakene skal være forsvarlige. En klar forskjell er at det foreligger en lovfestet forsvarlighetsnorm på både tjeneste- og individnivå i kommunens helse- og omsorgstjenester, mens det av lovens ordlyd kun ligger på tjenestenivå i barnevernsaker. En annen forskjell er at forsvarlighetskravet i helse- og omsorgstjenester adresserer personalets kompetanse og grensene for hvilke arbeidsoppgaver 
de kan ta på seg, og spesifikt fremhever kommunens ansvar for å tilrettelegge for at personalet kan oppfylle sitt forsvarlighetskrav.

$\AA ̊$ A motta velferdstjenester fra helse- og omsorgstjeneste kan som tidligere nevnt oppleves som mindre inngripende og stigmatiserende enn barneverntiltak. Barnevernets hjelpetiltak betinger barnets særlige behov for det, grunnet forhold i hjemmet eller andre forhold (bvl. § 4-4, 2. ledd) og er således ment for barn som er i en form for risiko. Et særtrekk ved barneverntjenestens intervensjon er deres tydeligere myndighetsrolle og adgang til makt. Foreldre og/eller barn kan eksempelvis ikke motsette seg en undersøkelse etter lovens § 4-3. Barneverntjenester innebærer derfor større inngrep i privat- og familieliv og autonomi enn helse- og omsorgstjenester og dermed større risiko for barnets og familiens rettssikkerhet. Ut fra et perspektiv om proporsjonalitet er det mulig å argumentere at forsvarlighetskravet bør skjerpes ut fra hvor inngripende tjeneste/-tiltaksformer instansen råder over, slik at forsvarlighetskravet står i forhold til barneverntjenestens målgruppe, barn i risiko og særlige mandat.

Å implisitt legge til grunn at kravet om hensynet til barnets beste i stor grad skal være beskrivende for innholdet $\mathrm{i}$ barneverntjenestens forsvarlighetskrav, innebærer ikke entydig en sikring av barnets rettsikkerhet. Kane (2016, s. 64) problematiserer at lovkravet om barnets beste knyttes til valg av tiltak (bvl. § 4-1), og påpeker at barnets beste må være det grunnleggende hensyn i barneverntjenestens arbeid i både kartlegging, vurderinger og beslutninger, og må omhandle både handlinger og avgjørelser. Dette vil være i tråd med ordlyden «alle handlinger som berører barn» i barnekonvensjonen artikkel 3, og i forarbeidene til ny barnevernlov (NOU 2016: 16) foreslås det at barnets beste skal plasseres inn under lovens $\S 2$ om formål og grunnleggende rettigheter. Forarbeidene fremhever også noen viktige hensyn i en barnets beste-vurdering, herunder barnets identitet, bakgrunn, synspunkter, sårbarhet, helse og utvikling samt behov omsorg, beskyttelse og for familie/relasjoner.

Av lovforarbeidenes forslag til $§ 4$ fremgår at forsvarlighetskravet til barneverntjenesten skal ha samme ordlyd som i dag, men supplert med ordlyden om at barnevernets virksomhet skal utøves «med respekt for og så langt som mulig i samarbeid» med barn og foreldre, og at det skal være forholdsmessighet mellom barnets situasjon og behov og barnevernets tiltak og gjennomføring av disse. Selv om dette er en utdyping i forhold til dagens ordlyd, fremstår forsvarlighetskravet fortsatt som vagere enn helselovgivningens forsvarlighetskrav. Det kan stilles spørsmål om hvorvidt forsvarlighetskravet sikrer barnets rettssikkerhet. Jeg har tidligere sitert lovforarbeidene til helsepersonelloven angående forsvarlighetskravet, hvor det 
ansvarlige departement fremholdt at en «konkretisering av forsvarlighetskravet vil tydeliggjøre kravet og dets innhold» (Ot.prp. nr. 13 (1998-99), pkt. 4.2.5.1). På barnevernområdet uttalte det ansvarlige departement i lovforarbeider til endringer i barnevernloven (Prop. 106 L (2012-2013), pkt. 17.4) at «[e]t lovfestet krav vil gi et viktig signal [..] om standarden for barnevernets arbeid», men at det på grunn av kontinuerlig kompetanseutvikling på barnevernområdet «verken er mulig eller hensiktsmessig å gi en detaljert og uttømmende beskrivelse av hva som vil være innenfor eller utenfor kravet til forsvarlighet».

Både lovtekst og lovforarbeider synes å antyde at utøvere og mottakere av kommunale barneverntjenester har et mindre behov for konkretisering av forsvarlighetskravet enn utøvere og mottakere av kommunale helse- og omsorgstjenester. Departementets uttalelse i barnevernlovens forarbeid tyder også på at man anser kompetanseutvikling som et større hinder for å konkretisere forsvarlighetskravets innhold innenfor barneverntjenester enn i helse- og omsorgstjenester. Med tanke på hvor inngripende en barneintervensjon er i barnets og familiens privatliv og familieliv, og i barnets oppvekst, er det grunn til å stille spørsmål om ikke forsvarlighetskravet burde vært særskilt godt konkretisert i barnevernloven.

\section{Verdig og omsorgsfull utøvelse av barneverntjenester (6.2)}

Helse- og omsorgstjenestelovens og helsepersonellovens forsvarlighetskrav knyttet til «verdig» tjenestetilbud og «omsorgsfull hjelp» kan også utgjøre et bidrag til forsvarlig organisering og tjenesteutøvelse i barneverntjenesten. Barnevernets intervensjon innebærer inngrep av ulik form og ulik alvorlighetsgrad, og barn og foreldre har menneskerettslig krav på respekt for sitt privatliv og familieliv (EMK art. 8, BK art. 16). Barnets rett til at alle handlinger og avgjørelser skal være best for det, tilsier også at barneverntjenestens tjenesteut $\varnothing$ velse skal være verdig og omsorgsfull. I lovforslaget til ny barnevernlovgivning (NOU 2016: 16) foreslås det et tillegg til barnevernlovens forsvarlighetskrav i § 4 ved at barnevernets virksomhet skal utøves «med respekt for og så langt som mulig i samarbeid med barnet og barnets foreldre».

Begrepene «verdig», «omsorgsfull» og «respekt» er verdiladede ord, og det er derfor vanskelig å vurdere og overprøve hvorvidt en tjenesteutøvelse faktisk er i tråd med verdiene. En kan vanskelig se for seg at barneverntjenestens ansatte, med sin maktposisjon overfor barn og foreldre i ulike krisesituasjoner, ikke skal ha plikt til å opptre omsorgsfullt, med respekt, 
verdighet, innlevelse, imøtekommenhet» og ha «vanlig god folkeskikk» (jfr. Molven, 2006). Lovforslaget om at barneverntjenestens forsvarlighetskrav også skal omfatte samarbeid med barnet og foreldrene, kan gjøre disse til mer tydelige aktører i egen sak. Samtidig vil ikke dette representere et samarbeid mellom likeverdige parter fordi forholdet preges av en sterk makt-avmaktsposisjon mellom partene, hvor familien og særlig barnet er i en særskilt svak og sårbar posisjon. Det er derfor verdt å vurdere om ikke også barnevernlovens forsvarlighetskrav bør spesifisere krav om verdige tjenester og omsorgsfull hjelp.

\section{Lovfestet krav til kompetanse i barneverntjenester (6.3)}

Forsvarlighetskravet i helse- og omsorgstjenesteloven og helsepersonelloven har et tydelig fokus på kompetanse på både tjenestenivå og individnivå, noe som mangler i barnevernlovens forsvarlighetskrav. Barnevernlovutvalget ønsker heller ikke å ta inn et slikt krav i ny barnevernlov og begrunner det med at «[d] et kan være flere ulike forklaringer» på mangelfull kompetanse». Samtidig tilkjennegir utvalget at forsvarlighetskravet fordrer «tilstrekkelig kompetanse og nødvendige faglige kvalifikasjoner» (NOU 2016: 16, pkt. 5.5.1).

Dersom en overfører innholdet helselovgivningens forsvarlighetsbestemmelser til barneverntjenesten, vil det på tjenestenivå fremheve kommunens ansvar for å sikre adekvat kompetanse i barneverntjenesten, for å tilpasse ansvarsområder og arbeidsoppgaver til personellets kompetanse og for å organisere driften slik at personellet har tid og ressurser til utøve sitt arbeid på en forsvarlig måte. På individnivå vil det tydeliggjøre at barnevernansatte ikke skal påta seg arbeidsoppgaver og vurderinger de ikke har tilstrekkelig juridisk og faglig kompetanse til, og at de skal innhente bistand fra bedre kvalifisert personell når arbeidsoppgaver og vurderinger gjør det nødvendig. For barneverntjenestens personell kan det omhandle å rådføre seg med kollegaer og/eller leder i egen tjeneste, men det kan også omhandle å rådføre seg med Statens helsetilsyn, som har faglig tilsynsansvar for barneverntjenesten, og/eller Fylkesmannen, som har tilsynsansvar for instansens oppfyllelse av lovpålagte plikter (bvl. § 2-3 b, 1. og 2. ledd).

I media har det vært fremsatt kritiske spørsmål med tanke på forholdsmessigheten mellom de sosialfaglige utdanninger og de utfordringer som kandidatene skal arbeide med i

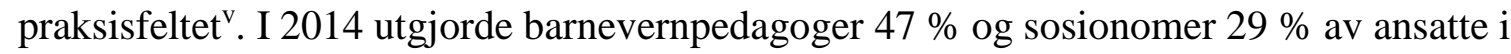
barneverntjenester i norske kommuner (NOU 2016: 16, pkt. 5.5.1.3). Disse har en treårig bachelorutdanning, som vanskelig kan gi rom for tilstrekkelige dybdekunnskaper innenfor alle 
de fagområder utdanningen omfatter, tilpasset det alvor og den kompleksitet som kommunale barneverntjenester representerer. Et uttalt kompetansekrav ut over bachelorgrad bør derfor vurderes for denne instansen, fulgt av фkonomiske ressurser som muliggjør at de ansatte kan oppfylle sitt forsvarlighetskrav i den enkelte sak.

Barnevernpedagoger og sosionomer omfattes ikke av et autorisasjonskrav, noe helsepersonell gjør. Helsepersonellovens autorisasjonsordning omfatter 29 yrkesgrupper, herunder vernepleiere, som har en kombinert helse- og sosialfaglig utdanning. Disse yrkesgrupper må tildeles autorisasjon for å utøve sitt yrke, og autorisasjonen kan tilbakekalles ved eksempelvis «grov mangel på faglig innsikt, uforsvarlig virksomhet [..], grove pliktbrudd» (hpl. §§ 48, 48a, 53 og 57). Fellesorganisasjonen for barnevernpedagoger, sosionomer, vernepleiere og velferdsvitere (FO) Ønsker en tilsvarende autorisasjonsordning for barnevernpedagoger og sosionomer og uttaler ${ }^{\mathrm{vi}}$ at

«[d]et er urimelig at de utsatte gruppene som mottar tjenester fra våre profesjoner, ikke skal ha den tryggheten som autorisasjon gir og at våre profesjoner ikke ligger under samme krav til forsvarlighet som grupper av helsepersonell».

Kvisvik og Stang problematiserer i en kronikk ${ }^{\mathrm{vii}}$ at barnevernets ansatte blir utpekt som de ansvarlige når norsk barnevern kritiseres, mens «ansvarlige politikere og kommuneledelse står feigt i skyggen». Det er grunn til å fremheve at forsvarlighetskravet i barneverntjenester ikke begynner først hos den enkelte ansatte, men hos politikerne, som har ansvar for å «gi og oppheve lover» og å «bevilge de pengesummer som er nødvendige for å dekke statens utgifter» (Grunnloven § 75). Fra politisk hold kan en dermed fremme forsvarlighet gjennom lovgiveransvaret ved å lovfeste kompetansekrav til arbeid i kommunal barneverntjeneste, både gjennom en regulering av hvilke yrkesgrupper som skal bemanne tjenestene, gjennom mer utdanning enten ved krav om mastergrad eller femårig barnevernutdanning og gjennom autorisasjonsordning. Gjennom bevilgningsansvaret kan de ansvarlige politikerne besørge tilstrekkelige bevilgninger til de nødvendige kostnader.

\section{Oppsummerende betraktninger (7)}

Barnevernansattes tjenesteutøvelse innebærer stor grad av skjønn, både faglig og juridisk, $\mathrm{i}$ saker med helt individuelle problemstillinger. Graver (2015, s. 86-87) fremhever hvordan forvaltningens forsvarlighetskrav er «et fokus på individets stilling i forvaltningsprosessen», 
og at dette kan utfordres ved at forvaltningsorganer og profesjonsutøvere kan inneha og/eller utvikle egne mål og normer, som kan gå «på tvers av [...] hensynet til enkeltindividet». Kane (2015) viser til at saksbehandlere ved Nav beskriver faktorer som legalitet, formålstjenlighet, forsvarlighet, individualitet, helhetssyn og likebehandling som idealer for $\sin$

skjønnsutøvelse. Samtidig fremhever de at deres idealer utfordres av faktorer som tidspress, $\phi k$ konomi samt etatsinterne instrukser og tradisjoner. Selv om nevnte unders $\varnothing$ kelse omhandler saksbehandlere i Nav, kan det tenkes at saksbehandlere i barneverntjeneste utfordres av de samme faktorene. Det kan resultere i praksis som går på tvers av hensynet til barn og deres familier, og slik innebære en risiko for uforsvarlig tjenesteutøvelse.

Forsvarlighet på både tjeneste- og individnivå påvirkes i stor grad av hvilke prioriteringer barnevern har på politisk hold. Myndighetenes ansvar for å sikre barnets menneskerettslige krav på beskyttelse omfatter å besørge lovgivning, organisering og bevilgninger som i tilstrekkelig grad sikrer barnet slik beskyttelse. Når lovforarbeidene beskriver forsvarlighet som «fagkunnskap» og «utvikling av fagkunnskap fra utdannings- og forskningsinstitusjoner», synes man å legge til grunn at det eksisterer et grunnleggende krav om faglig kompetanse for å utøving av barneverntjenestens saksbehandling. Lovgiver er imidlertid taus om hvilken kompetanse som kreves, angående innhold, kvalitet og kvantitet. Det kan imidlertid tenkes at å skulle beskrive et kompetansekrav tilsvarende en treårig utdanning, i et praksisfelt med så komplekse utfordringer, ville demonstrere nettopp den manglende forholdsmessighet. Det ville i så fall synliggjort behovet for lovkrav om utdanning ut over bachelorgrad.

Barnevernarbeid har to særlige kjennetegn; barneverntjenesten kan intervenere $\mathrm{i}$ familielivet mot barnets og/eller foreldrenes vilje, og målgruppa er barn i risiko. Det er derfor grunn til å reise spørsmål om formålstjenlighet og rettssikkerhet når lovgivningen gir barn og deres familier svakere sikring av forsvarlighet når de mottar barneverntjenester enn når de mottar kommunale helse- og omsorgstjenester.

\section{Referanser (9)}

Barne-, ungdoms- og familiedirektoratet (2017). Saksbehandlingsrundskrivet. https://www.bufdir.no/barnevern/Fagstotte/saksbehandlingsrundskrivet/

Eckhoff, T. \& Helgesen, J.E. (2001). Rettskildelaere. Oslo: Universitetsforlaget.

Eckhoff, T. \& Smith, E. (2014). Forvaltningsrett. 10. utg. Oslo: Universitetsforlaget. 
Fellesorganisasjonen (2015). Yrkesetisk grunnlagsdokument for barnevernpedagoger, sosionomer, vernepleiere og velferdsvitere. https://www.fo.no/yrkesetikk/yrkesetiskgrunnlagsdokument-article227-150.html.

Fylkesmennene i Hordaland, Rogaland og Troms (2016). 'Dei forsto meg ikkje'. Tilsynsrapport 19. september 2016.

Graver, H.P. (2015). Alminnelig forvaltningsrett. 4. utg. Oslo: Universitetsforlaget.

Haugland, R. (2016). Barnevern i små distriktskommuner. 2. utg. Oslo: Gyldendal Akademisk.

Helsedirektoratet. (2015). Samarbeid mellom barneverntjenester og psykiske helsetjenester til barnets beste. Rundskriv 21/2015.

Kane, A.A. (2015). Skjønn, lover og idealer. Stat og styring - Tidsskrift for politikk og forvaltning 01/2015. Oslo: Universitetsforlaget.

Kane, A.A. (2016). Barnets menneskerettslige krav på beskyttelse - En sammenligning av juridiske rammer for bekymringsmelding og undersøkelse i Norge og England. Norges barnevern, 93(1). Oslo: Universitetsforlaget.

Kjær, A.K.B. \& Mossige, S. (2013). Barnevernets henleggelser av meldinger som omhandler vold og seksuelle overgrep. Tidsskrift for familierett, arverett og barnevernrettslige spфrsmål. 11(2). Oslo: Universitetsforlaget.

Kjønstad, A. (2007). Helserett. Oslo: Gyldendal Akademisk.

Kjønstad, A., Syse, A. \& Kjelland M. (2017). Velferdsrett I. Grunnleggende rettigheter, rettssikkerhet og tvang. 6. utg. Oslo: Gyldendal Juridisk.

Kojan, B.H., Marthinsen, E. \& Christiansen, Ø. (2016). Beslutninger i meldingsarbeidet. I Christiansen, Ø. og Kojan, B.H. (red), Beslutninger i barnevernet. Oslo: Universitetsforlaget.

Kommunesektorens organisasjon (2017). Veileder - Håndtering av dokumentasjon $i$ barnevernet. Oslo: Kommuneforlaget.

Molven, O. (2006). Helse og jus. En innføring for helsepersonell. Oslo: Gyldendal Akademisk.

NOU 2016: 16. Ny barnevernlov. Sikring av barns rett til omsorg og beskyttelse. Barne- og likestillingsdepartementet.

Ot.prp. nr. 44 (1991-1992). Om lov om barneverntjenester (barnevernloven). Barne- og familiedepartementet.

Ot.prp. nr. 13 (1998-99). Om lov om helsepersonell (helsepersonelloven). Helse- og omsorgsdepartementet.

Ot.prp. nr. 68 (2007-2008). Om lov om endringer i lov 17. juli 1992 nr. 100 om barneverntjenester m.v. (barnesakkyndig kommisjon). Barne- og likestillingsdepartementet.

Prop. 91 L (2010-2011). Lov om kommunale helse- og omsorgstjenester m.m. (helse- og omsorgstjenesteloven). Helse- og omsorgsdepartementet.

Prop. 106 L (2012-2013). Endringer i barnevernloven. Barne- og likestillingsdepartementet. 


\section{Noter (8)}

i Se f.eks:

https://www.dagbladet.no/nyheter/advarer-om-krise-i-barnevernet/65345584.

https://www.aftenposten.no/meninger/debatt/i/1agw/Vi-trenger-en-felles-dugnad-for-et-bedre-barnevern. https://www.aftenposten.no/meninger/kronikk/i/vp9l/Kronikk-Det-er-noe-grunnleggende-galt-medbarnevernet. Alle lastet ned 12.10.2017.

ii Stavanger Aftenblad 30. januar 2016.

iii https://www.nrk.no/norge/antall-barnevernsklienter-doblet_-forsker-frykter-de-alvorlige-sakene-drukner1.12738843

iv https://www.ssb.no/barneverng/. Lastet ned 12.10.2017.

$\checkmark$ https://www.aftenposten.no/meninger/debatt/i/8MOOr/Medierevisjonen-Barnas-hjelpelose-hjelpere--AnkiGerhardsen. Lastet ned 09.11.17.

vi https://www.fo.no/uttalelser-fra-landsstyret/fo-krever-autorisasjon-av-barnevernspedagoger-ogsosionomer-na-article8633-310.html

vii https://www.aftenposten.no/meninger/kronikk/i/woJMG/Politikerne-star-feigt-i-skyggen-nar-barneverneter-skyteskive--Mimmi-Kvisvik-og-Elisabeth-Gording-Stang. Lastet ned 09.11.17. 